UDC 378.147.016:[811.111+811.112.2]:33-051]

DOI https://doi.org/10.32841/2409-1154.2019.40.2.14

\author{
Matiychak A. A., \\ Candidate of Philological Sciences, Associate Professor \\ Department of Foreign Languages for Humanitarian Colleges \\ Yuriy Fedkouych Chernivtsi National University
}

\author{
Muradkhanian I. S., \\ Candidate of Philological Sciences, Associate Professor \\ Department of Foreign Languages for Humanitarian Colleges \\ Yuriy Fedkouych Chernivtsi National University \\ Cherska Zh.B., \\ Candidate of Philological Sciences, Associate Professor \\ Department of Foreign Languages for Humanitarian Colleges \\ Yuriy Fedkouych Chernivtsi National University
}

\title{
FORMATION OF FOREIGN LANGUAGE COMPETENCE IN STUDENTS OF ECONOMIC SPECIALITIES
}

\begin{abstract}
Summary. The purpose of the article is to investigate the mechanisms of forming foreign language competence in students of economics in the frameworks of Business English and German for Business courses on the basis of modern vocabulary and a series of vocabulary and communication exercises, which should result in oral and written communication on the professional level.

In such a way we try to reinforce the students' grammar skills working on contextual examples and practice exercises. It is of utmost importance that the information of both the general professional field and narrowly specialized aspects be trained comprehensively in reading, listening, writing and speaking, which creates favorable prerequisites for forming the communicative competence of specialists in economy and future businessmen. So, in particular, one and the same theme is optimally revealed, in our opinion, on authentic professional material. The topics of the course include such generally professional aspects as: company structure; career choices and finding a job; preparing a resume; job interview; e-mail etiquette; e-commerce; internet sales; telephoning; ordering, and checking information; complaining; writing memos, completing order forms; creating marketing plans and conducting meetings; effective advertising techniques; presenting products; banking and accounting; dealing with bank accounts and credit cards; corporate culture etc.

The analysis shows that the model of "listening, reading, writing, speaking" is the most acceptable for successful business communication. The result of using such a mechanism is the development of communicative competence of future specialists, who are able to understand the interlocutor and to respond not only at everyday, but also on the modern professional level, be able to reproduce and find relevant information and communicate on business in writing.
\end{abstract}

Key words: competence, reading, listening, writing, speaking, business.

Formulation of the problem. Currently the advanced level of foreign languages command in the professional field becomes especially important. Foreign language competence is a necessary component of the professional training of future economists. Specialists who are fluent in English and have knowledge of one or more foreign languages are in demand in the labor market. That is why the methods and techniques of forming foreign language competence for students of economic specialties who will work in the field of international business remain relevant.

Analysis of recent research and publications. Many researchers have devoted their publications to the problems of foreign language competence formation, focusing on various psychological and socio-cultural aspects, as well as on the peculiar types of speech activity: reading and listening, or writing and speaking $[1 ; 2]$. However, the successful implementation of business ideas in the international area requires the knowledge, skills and abilities of all aspects of speech activity in modern language material [3-10], as future business professionals need to be able to obtain and distinguish a lot of the necessary information by reading it, listening to partners, writing business letters and communicating on different levels in modern conditions.

Therefore, the purpose of the article is to investigate the mechanisms of forming foreign language competence in students of economics by means of English and German in the frameworks of Business English and German for Business courses on the basis of modern vocabulary and a series of vocabulary and communication exercises, which should result in oral and written communication at the professional level.

Outline of the main research material. The main task of the course "Business English" is to empower students with the language and life skills they need to carry out their career goals and practice the language in real life scenarios. In the process of teaching it is advisable to develop the students' self-confidence to succeed in professional and social encounters within English-speaking global community. So, the four skills of listening, speaking, writing and reading are being developed within professional contexts. Due to the necessity to develop the life skills students need to deal with situations they will encounter in the job market. In this way at the classes we read and discuss job advertisements, fill in forms, prepare resumes and interview procedures, write e-mails, discuss the functions of the Human Resources department. 
Informative reading of texts gives an overview of a particular topic. Each includes a lot of comprehension and vocabulary exercises and discussion activities. E.g.: we read the text about company structure [7, p. 21-25]. Before reading about traditional company organization we check students' understanding of some basic terms by matching up the words and definitions. After reading basic information, students answer comprehension questions. Then they are asked to perform vocabulary exercises - matching up the verbs and nouns to make collocations, discussing the goals of the finance, marketing and production departments; classifying business strategies according to which the department would probably favour them.

Working on the subject of career choices and finding a job [10, p. $8-11 ; 7$, p. $30-33]$ we ask students to share information about people they know who are looking for a job and who have just found work. After reading the list of ideas in the books - job advertisements, skills and qualifications needed for each job, we encourage students to share their ideas with the rest of the class. Our students are offered to talk about their specific interest in business. They identify strengths and weaknesses in the area of business. Then we ask the students to read the job ads again and underline the skills and qualifications that are needed for each job. We organize students into pairs and offer them to compare jobs advertised in the ads mentioning advantages that some of the jobs have. At the next lesson our students look closely at how to prepare a good resume and what it should include [7, p. 34-36]. Students listen to and read the resumes of several applicants for a job, evaluate the strengths and weaknesses of each candidate. We discuss the importance of planning and preparing a resume carefully. Students listen to the monologue of a human resources manager, giving some advice about preparing a resume. Then students are encouraged to draft their own resumes and read them suggesting corrections and additions. One of the classes is devoted to another important step in the job-hunting process - the cover letter that accompanies an application for a job, considering the important matter of formal and informal language [10, p. 72-75]. Students listen to the speaker giving some advice on e-mail etiquette language [8, p. 23-27], comment on what they heard and draft their own e-mails, reading them later aloud.

Preparing the students of economics to the process of sales we describe the characteristics of a good salesperson, analyze different sales situations, relations with the customers. We teach students to deal with customer complaints [8, p. 32-35], prepare sales presentation [8, p. 111-114], analyze internet sales.

We encourage students to look at specific sales situations, in particular, placing an order for some goods over the phone. Students listen to conversations to complete order forms, consider the dialogues taking place between people involved in sales and their regular customers. After listening audio, students complete the notes with the correct information, focusing on the passive voice which is often used in transactions, such as ordering, delivering, checking information and complaining. E.g.: When making a complaint, students are proposed to keep the following points in mind:

- Make sure you are speaking to the person who is in a position to help you. Ask questions to check who exactly you are talking to and take notes.

- Stay as unemotional as possible. Blaming the person you are calling will not help. Separate the problem from the person. Be firm, but polite.
- State the problem clearly and calmly. Include as much relevant detail as possible, including names, times, places, previous contacts, and so on.

- State exactly what you want the person you are calling to do.

- Check when you can expect results/feedback from the person you are speaking to [10, p. 28]. It is advisable to divide the class into teams; so that one team is making complaints, another is dealing with complaints; e.g.:

- Let the caller express their complaint. Don't interrupt, but try to get all the details. Take notes.

- Once they have finished complaining, summarize the complaint; clarify any unclear details and show empathy.

- Apologize. Do not try to make excuses but provide an explanation if the customer requests one.

- State what you are going to do to resolve the situation.

- Tell the customer when they can expect results / feedback.

- Stay calm with the customer at all times. Separate the problem from the person $[10$, p. 32]. Then it is useful to do a series of vocabulary exercises, such as: Match the two halves of the sentences and put the sentences in the correct category:

1. To show regret / empathy; 2. To find out what the problem is; 3. To apologize; 4 . To propose a solution/to promise action.

\begin{tabular}{|l|l|}
\hline 1. Could you bear with me & A ... gets done by the end of the week for \\
2. I'm terribly sorry for the... & $\begin{array}{l}\text { 10 minutes... } \\
\text { B... for our part in this. }\end{array}$ \\
3. I can imagine... & C... problems that you're experiencing. \\
4. I propose that... & D ... have been dreadful. \\
5. I'll make sure that it... & E... we offer you some sort of compensation \\
6. That must... & F ... exactly what happened? \\
7. Could you tell me... wrong here? & G... while I get to the bottom of what went \\
8. I do apologize... & H... that was terrible. \\
\hline
\end{tabular}

Also students listen to the sentences, noting how the key words are stressed to make the speaker's meaning and intention clear.

1. I'm terribly sorry for the problems that you're experiencing.

2. I propose that we offer you some sort of compensation.

3. I'll make sure that it gets done by the end of the week.

4. I do apologize for our part in this. [10, p. 34].

During the next step they practice writing memos, completing order forms. Then, we organize students in pairs to create and roleplay situations based on real life cases of customer dissatisfaction, presenting their role plays for the rest of the class. During the lesson our students listen to the audio - some advice and warnings about online shopping taking brief notes, then discuss growth of e-commerce, the commercial potential of the worldwide web sharing their experiences, options related to the world of online commerce. In small groups students present the steps for setting up online store participating and commenting on the topic. One of the most important steps in our course is to teach students to present products, brands [10, p. 52-55], create marketing plans and conduct meetings [10, p. 36-39].

At the classes devoted to marketing the product we motivate the students to consider the techniques that advertisers use to make their advertising effective [7, p. 69-72]. We listen to the material focusing on various types of advertising. We explain some of the abbreviations used in the ads, ask students to say where they might expect to find ads in this format (magazines, newspapers, leaflets) and discuss how the advertisers of these products would advertise in other media: TV, billboards, on the Internet. In pairs students discuss current advertisements that have caught their 
attention recently and explain what they like and dislike about them. Students try to include some ads for products made by companies well-known for their logo or trademark, then clarify definitions of such terms as: brand, trademark, logo; listen to the dialogue on the subject of brands and branding, then mark the statements that are true according to what they heard. We draw students' attention to compound adjectives like cost-cutting, customer-friendly, mouth-watering, long-lasting used in the world of advertising and ask them to find more examples and read them aloud. At the lessons we try to teach our students how to chair a meeting. Firstly they study key vocabulary of meetings, then listen to audio material concerning different meetings: receiving information from managers, giving progress reports to managers or to a team, discussing day-to-day departmental matters, making decisions at the meetings with other managers.

We inspire students to talk about their experience of other types of meetings (e.g. student meetings or discussion groups). We mention cultural differences among people from different parts of the world [7, p. 26-29]. Then we divide the learners into groups to represent the role-play of the meeting discussing conflicting ideas, provoking discussions, giving the chair (role A) an opportunity to use controlling language. We ask students what phrases they know to show that they completely agree or disagree with someone - giving strong, neutral or weak opinions. We divide the class into pairs - learners take turns to give their opinions agreeing or disagreeing with their partners. One of the students represents the role of the Chief Executive chairing the meeting. He explains the meeting's objective, decides who can speak and when, summarizes other students' arguments, decides when the meeting should come to the end what decision should be reached. Our students discuss financial issues: investment options including online finance, opening a bank account, managing business expenses, describing economic issues that affect business, etc.

Teaching how to deal with financial matters, we firstly discuss students' expenses; students brainstorm and exchange their ideas. Then they perform a series of activities in which students listen to and discuss information about expected expenditures, comparing their expenditures while they attend university or live at home, speak about the income they expect to have for the coming year or save from summer job. We organize students into pairs and spur them on discussing real figures of their budgets, considering the importance of balancing income and expenditures. We focus on vocabulary dealing with bank accounts, credit cards [7, p. 73-74]. We discuss recent news items related to individual banks or to the banking system of different countries [7, p. 73-76; 8, p. 18-22; 9, p. 80-89]. Our students listen to the examples of the different banking services advertising from TV commercials, magazine and newspaper ads. We open up the discussion for the whole group, inviting students to share information about special student deals or efforts that banks advertised. The students are encouraged to discuss the subject of credit cards, sharing their experiences and impressions. Writing activities of the lesson include filling in the application for a credit card, memorizing definitions of the terms: collateral, withdraw, charges, balance and using them in the sentences. Then students draft the letters to the bank concerning the problem with credit card debit, requesting a grant to cover the cost of their studying, describing their long-range plans.

At the classes we analyze cultural differences in business deals, describe a variety of corporate cultures, and discuss global issues that affect the business world. Some classes are devoted to cultural issues when we read the information, discuss and evaluate the experience of a person adapting to differences in a foreign country. Students listen to five people talking about their impressions working in another culture, then, take notes about the things that they found different or unusual in the business culture of the other country. Students speculate about foreign companies, banks, business operating in our country; foreign workers employed with these companies; foreign students currently taking courses at our universities. We encourage students to work in pairs and then open up the discussion for the whole group.

As to writing activities we ask students to write a personal letter to a friend describing their imaginary experience while adapting to life and work in another country with different culture.

While dealing with the culture of a particular company students discuss the meaning of some key terms that they will use later at the lesson (inherit, insist, interfere, encourage, outsider, novel, challenging), listen and read material for discussion, speak about corporate culture. They listen to the audio - three people talking about the organizational culture of different companies they work for. Students are asked to make notes and match each employee with the most appropriate term from the box. E.g.: Student 1: top controlled = authoritarian,

Student 2: assessing reaction of candidates = innovative;

Student 3: open-plan = open and inclusive.

Then we organize students to share anything they know about native companies - large and small, the types of organizational culture that each company exemplifies. After that students are asked to present role plays: manager delegates a task to an employee interacting with the staff working beneath him. Then our students read short biographies of entrepreneurs who have founded global enterprises, completing comprehension tasks and vocabulary exercises.

In such a way we try to reinforce the students' grammar skills working on contextual examples and practice exercises.

As well as Business English, The course "German for Business" (Deutsch für Business) is an important aspect in the formation of foreign language competence of students of economic specialties in the University curricula. In order to be successful in the future, students should be aware of the particularities of their professional field, as well as be able to communicate with foreign partners. The topics of the German-language information base for economists include such generally professional aspects as "Choice of a profession", "Submission of resume", "Job interview", "Work place and working hours", "Employment contract", "Workplace safety", "Salary" [3; 4], as well as information on highly specialized areas: "Enterprise. Types of Enterprises", "Exhibition-Fair", "Offer", "Negotiations" [5], etc.

It is of utmost importance that the information of both the general professional field and narrowly specialized aspects be trained comprehensively in reading, listening, writing and speaking, which creates favorable prerequisites for forming the communicative competence of specialists in economy and future businessmen. So, in particular, one and the same theme is optimally revealed, in our opinion, on authentic professional material through a series of exercises. As practice shows, listening-based exercises have become an effective learning algorithm of Practical German that begins with listening as a warm-up activity and familiarization with the topic such as "Submission of resume". E.g.: Hören Sie das Gespräch und ergänzen Sie die Sätze: 
Herr Bratischko hat die Stellenanzeige am der Zeitung gefunden.

Er möchte sich als bewerben.

Ermöchte wissen, welche das Autohaus benötigt.

Für die Bewerbungsunterlagen braucht er ein Bewerbungsschreiben, einen Lebenslauf, Zeugnisse und eine Kopie von seinem

Die Bewerbung soll er an senden $[3$, p. 50].

The next stage is reading with exercises to train new vocabulary and understanding of the text on a professional topic: Was passt? Ordnen Sie zu?

\begin{tabular}{|l|l|}
\hline der Hersteller 1. & A. die Zeit, die man in einem Beruf arbeitet \\
das Profil 2. & B. Kontrolle und Pflege der Technik \\
die Berufserfahrung 3. & C. hier: eine Firma, die etwas produziert \\
die Instandhaltung 4. & D. Qualifikationen und Kompetenzen einer Person \\
die Auffassungsgabe 5. & E. alle Aufgaben, die zu einer Stelle gehören \\
das Aufgabengebiet 6. & F. die Fähigkeit, etwas zu verstehen [3, p. 59]. \\
\hline
\end{tabular}

To consolidate the studied material, vocabulary generalization exercises are effective as a means of systemizing concepts.

Arbeit und Beruf. Ordnen Sie die Oberbegriffe zu: die Karriere, die Ausbildung, die Arbeitszeit, der Arbeitsvertrag, das Unternehmen, die Arbeitssuche

1) die Ausbildung: die Lehre - das Studium - das Praktikum

2) _ : der Lebenslauf-das BewerbungsschreibenVorstellungsgespräch

$\begin{array}{cl}\text { 3) } & \text { : die Abteilung-der Chef-die Fachleute } \\ \text { 5) } & \text { :das Gehalt-die Arbeitszeit-die Tätigkeit } \\ \text { Nebenjob } & : \text { die Vollzeitstelle - die Teilzeitstelle - der } \\ \text { 6) } & \text { : die Weiterbildung - die Beförderung - die }\end{array}$ Berufserfahrung [6, p. 20].

Submitting employment information (CVs) involves preparation in the form of vocabulary exercises for writing resume and biography in German. These exercises include the training of grammatical constructions by forming sentences, filling in the missing lexical units, arranging the parts of the resume in the correct order, writing a biography and a resume on the submitted sample.

E.g.: Ergänzen Sie die fehlenden Wörter in den Einleitungssätzen: ausgeschriebene, gelesen, suchen, stelle, bewerbe

1) Ich stelle mir vor als ...

2) Sie eine / $n$...

3) Die von Ihnen Position als ...

4) Mit großem Interesse habe ich Ihre Anzeige und mich um ... [4, p. 41].

Ordnen Sie die Wörter und schreiben Sie Schlusssätze: auf, Bewerbung, ein, freie, geweckt, hat, ich, Ihr, Interesse, meine, mich, Vorstellungsgespräch, wenn.

Wenn meine Bewerbung Ihr Interesse geweckt hat, freue ich mich auf ein Vorstellungsgespräch... [4, p. 41].

With regard to speaking on the subject, a significant result is demonstrated by the preparatory exercises in the question-answer model on biographical data, professional skills and personal interests of the applicant for the vacancy.

This model can be refined by making dialogues based on the principle of interlocutors: "job applicant - friend" or "applicant - family member" (questions and answers from the first-person singular-ich-Form and the second-person singular-du-Form), the "applicant-employer" (dialogue in the form of polite request -
Sie-Form), "Head of HR department - Chief Executive" (questions and answers regarding the candidate for a third-person singular position er-Form to characterize a man and sie-Form to describe the qualities of a woman as a job applicant). The final step in developing the speaking skills should be the presentation of the applicant for the job in the form of a presentation monologue (first-person singular / ich-Form) and presentation of the head of personnel to the boss (third-person singular er / sie-Form).

Conclusions. As the analysis shows that among the mechanisms of foreign language competence formation in students of economic specialties by means of English and German, the model of "listening, reading, writing, speaking" is the most acceptable for successful business communication in the international area. The implementation of this model is based on a series of vocabulary and communication exercises. The result of using such a mechanism is the development of communicative competence of future specialists, who are able to understand the interlocutor and to respond not only at everyday, but also at the modern professional level, able to reproduce and find relevant information and conduct business communication in writing.

In the future, it is expedient, in our opinion, to investigate the impact of modern video materials on the formation of foreign-language competence of students-economists within the specified subject area of business.

\section{References:}

1. Методика навчання іноземних мов і культур: теорія і практика : підручник / О. Бігич, Н. Бориско, Г. Борецька та ін. ; за заг. ред. С. Ніколаєвої. Київ : Ленвіт, 2013. 590 с.

2. Тарнопольський О.Б. Методика навчання іншомовної мовленнєвої діяльності у вищому мовному закладі освіти. Київ : Фірма «ннос», 2006. 248 c.

3. Becker J. Merkelbach M. Pluspunkte Beruf-Deutsch am Arbeitsplatz. A2+/ B1. Berlin : Cornelsen, 2014. 248 S.

4. Gerhard C. Menschen im Beruf. Bewerbungstraining. Deutsch als Fremdsprache. A2+/ B1. München : Huber Verlag, 2017. $80 \mathrm{~S}$.

5. Eismann V. Wirtschafts-Kommunikation Deutsch. Berlin, München, Wien, Zürich, New York : Langenscheidt, 2000. 185 S.

6. Lütke M., Moritz U., Rodi M. Aspekte neu. Mittelstufe Deutsch. Intensivtrainer B2. Stuttgart : Ernst Klett Sprachen, 2017. 96 S.

7. Mackenzie I. English for Business Studies. A course for Business Studies and Economics students. Cambridge University Press, 2010. 191 p.

8. Mackenzie I. English for the Financial Sector. Cambridge University Press, 2008. 155 p.

9. Pratten J. Absolute Financial English: English for Finance and Accounting. Cengage Learning. Surrey, England : Delta Publishing, 2009. 136 p.

10. Schofield J., Osborn A. Collins English for Business. SPEAKING. London : HarperCollins Publishers, 2011. 129 p.

Матійчак А., Мурадханян І., Черська Ж. Формування іншомовної компетентності у студентів економічних спеціальностей

Анотація. У статті проаналізовані механізми формування іншомовної компетентності у студентів-економістів засобами англійської та німецької мов у рамках курсів «Англійська у бізнес-сфері» (Business English) i «Німецька мова для сфери бізнесу» (Deutsch für Business) на основі сучасної лексики та низки лексико-граматичних, комунікативних вправ, результатом яких має стати усне та писемне спілкування на професійному рівні.

Задля успішної професійної діяльності у майбутньому студенти мають бути обізнаними з особливостями 
ISSN 2409-1154 Науковий вісник Міжнародного гуманітарного університету. Сер.: Філологія. 2019 № 40 том 2

їхньої професійної сфери, а також уміти спілкуватися 3 іноземними партнерами. Тематика інформативної бази для економістів включає як загальнопрофесійні аспекти «Вибір професії», «Подання резюме», «Співбесіда під час працевлаштування», «Місце роботи та робочий час», «Трудовий договір», «Безпека на робочому місці», «Заробітна платня», так і інформацію щодо вузькоспеціалізованих сфер «Підприємство. Види підприємств», «Виставка-ярмарок», «Пропозиція», «Переговори», «Телефонні розмови», «Інтернет-торгівля», «Замовлення товарів», «Складання маркетингових планів», «Реклама», «Банківська діяльність», «Рахунки», «Оплата та кредитні картки», «Організація зустрічей», «Корпоративна культура» тощо.

Надзвичайно важливо, щоб інформація загальнопрофесійної сфери та вузькоспеціалізовані аспекти тренува- лися комплексно на автентичному професійному матеріалі за допомогою вправ.

Аналіз механізмів формування іншомовної компетенції у студентів економічних спеціальностей засобами англійської та німецької мов, необхідної для успішного ведення бізнесу на міжнародній арені, дозволив встановити оптимальну модель «слухання, читання, письмо, говоріння». В основі реалізації цієї моделі лежить комплекс лексико-граматичних і комунікативних вправ. Результат застосування такого механізму - розвиток комунікативної компетентності майбутніх фахівців, здатних розуміти співрозмовника та відповідати не тільки на побутовому, а й на сучасному професійному рівні, уміти відтворювати та знаходити відповідну інформацію, вести ділове спілкування у писемній формі.

Ключові слова: компетентність, читання, слухання, письмо, говоріння, бізнес. 